\title{
Plant nematodes in South Africa. 12. Checklist of plant nematodes of the protected areas of the Eastern Cape Province
}

\begin{tabular}{|c|c|}
\hline \multicolumn{2}{|c|}{$\begin{array}{l}\text { Authors: } \\
\text { Mariette Marais }{ }^{1} \\
\text { Antoinette Swart }{ }^{1}\end{array}$} \\
\hline $\begin{array}{l}\text { Affiliations: } \\
{ }^{1} \text { Agricultural R } \\
\text { Council, Plant } \\
\text { Research Instit } \\
\text { South Africa }\end{array}$ & $\begin{array}{l}\text { esearch } \\
\text { Protection } \\
\text { tute, }\end{array}$ \\
\hline $\begin{array}{l}\text { Corresponden } \\
\text { Mariette Mara }\end{array}$ & $\begin{array}{l}\text { ce to: } \\
\text { is }\end{array}$ \\
\hline $\begin{array}{l}\text { Email: } \\
\text { maraism@arc. }\end{array}$ & agric.za \\
\hline $\begin{array}{l}\text { Postal address } \\
\text { Private Bag X1 } \\
\text { Queenswood } \\
\text { South Africa }\end{array}$ & $\begin{array}{l}34 \\
34, \\
0121\end{array}$ \\
\hline $\begin{array}{l}\text { Dates: } \\
\text { Received: } 11 \mathrm{D} \\
\text { Accepted: } 27 \\
\text { Published: } 17\end{array}$ & $\begin{array}{l}\text { ec. } 2013 \\
\text { Aug. } 2014 \\
\text { Nov. } 2014\end{array}$ \\
\hline $\begin{array}{l}\text { How to cite th } \\
\text { Marais, M. \& S } \\
2014, \text { 'Plant ne } \\
\text { South Africa. } 1 \\
\text { of plant nemat } \\
\text { protected area } \\
\text { Eastern Cape } \\
\text { Koedoe } 56(1) \text {, } \\
3 \text { pages. http:/ } \\
\text { org/10.4102/k } \\
\text { v56i1.1220 }\end{array}$ & $\begin{array}{l}\text { is article: } \\
\text { wart, A., } \\
\text { ematodes in } \\
\text { 2. Checklist } \\
\text { todes of the } \\
\text { s of the } \\
\text { rovince', } \\
\text { Art. \#1220, } \\
\text { /dx.doi. } \\
\text { oedoe. }\end{array}$ \\
\hline $\begin{array}{l}\text { Note: } \\
\text { Additional sup } \\
\text { information m } \\
\text { in the online v } \\
\text { this article as a } \\
\text { Appendix: http } \\
\text { org/10.4102/k } \\
\text { v56i1.1220-1. }\end{array}$ & $\begin{array}{l}\text { porting } \\
\text { ay be found } \\
\text { ersion of } \\
\text { an Online } \\
\text { ://dx.doi. } \\
\text { oedoe. }\end{array}$ \\
\hline $\begin{array}{l}\text { Copyright: } \\
\text { (C) 2014. The A } \\
\text { Licensee: AOSI } \\
\text { OpenJournals. } \\
\text { is licensed und } \\
\text { Creative Comn } \\
\text { Attribution Lic }\end{array}$ & $\begin{array}{l}\text { uthors. } \\
\text { IS } \\
\text { This work } \\
\text { ler the } \\
\text { nons } \\
\text { ense. }\end{array}$ \\
\hline Read online: & $\begin{array}{l}\text { Scan this QR } \\
\text { code with your } \\
\text { smart phone or } \\
\text { mobile device } \\
\text { to read online. }\end{array}$ \\
\hline
\end{tabular}

Soil-inhabiting nematodes, including plant-parasitic nematodes, are considered to be the most abundant multicellular organisms in the soil, and of particular interest since they are an integral part of the interlocking chain of nutrient conversions. Because of their abundance and relative susceptibility to both physical and chemical changes, these organisms are used as indicator organisms. The National Collection of Nematodes (NCN) consists of a core collection, the Meloidogyne Collection and the Juan Heyns Collection, which are housed at the Plant Protection Research Institute of the Agricultural Research Council in Pretoria. Vast amounts of biodiversity data are contained in NCN, and the digitising of the collection from 2007 to 2014 yielded unpublished locality information, especially datasets of plant nematodes reported from protected areas of the Eastern Cape. Two hundred and thirty plant nematode species belonging to 36 genera were reported from the Eastern Cape. Of these, only 80 were from protected areas, whilst 163 were from uncultivated areas (outside protected areas) and 148 from cultivated areas. Ten species were described from protected areas, namely Criconemoides silvicola, Meloinema silvicola, Ogma tuberculatum, Paralongidorus cebensis, Paralongidorus hanliae, Scutellonema tsitsikamense, Trichodorus vandenbergae, Xiphinema erriae, Xiphinema ornatizulu and Xiphinema simplex. Only M. silvicola, O. tuberculatum, P. cebensis and S. tsitsikamense were not reported from other provinces, suggesting endemism.

Conservation implications: The diversity of nematode fauna is not adequately protected as most nematode biodiversity in the Eastern Cape lies outside protected areas, with only 80 of the 230 plant-feeding nematode species in the province being reported from protected areas.

\section{Introduction}

The National Collection of Nematodes (NCN), one of the four national collections housed in the Biosystematics Programme of the Plant Protection Research Institute, Agricultural Research Council, Pretoria, was founded in the mid-1950s, with the first type specimens deposited in 1958. The National Collection of Nematodes consists of a core collection, the Meloidogyne Collection and the Juan Heyns Collection. The National Collection of Nematodes currently consists of 180000 specimens, of which 7140 are type specimens, mostly from southern Africa, but also from such diverse localities as Antarctica and the Amazon.

The type specimens of 510 species are currently deposited in NCN and we now know that 455 plant nematode or plant-feeding nematode species are reported from South Africa. The South African Plant-Parasitic Nematode Survey (SAPPNS) programme was initiated in 1987 to produce a comprehensive assessment of the nematode biodiversity resources of South Africa. One of the four objectives of SAPPNS is to compile an inventory of the plant nematodes of South Africa (Marais 2006). As part of this initiative, surveys were undertaken in various areas, including some of the protected areas of the Eastern Cape, in order to establish the incidence and distribution of plant nematodes in these areas (Van den Berg 1996). In this article, plant nematodes are seen as nematodes that feed on plants and therefore always have a tylenchoid stomatostyle, dorylaimoid odontostyle or trichodorid onchiostyle. This includes nematodes that have an ectoparasitic, endoparasitic or semi-endoparasitic life cycle (Yeates et al. 1993).

As recommended in the International Code of Zoological Nomenclature, locality data and host plant data are usually published as part of species descriptions. Apart from a checklist of the Tsitsikamma National Park (Van den Berg 1996), the nematode biodiversity information of the Eastern Cape had not been consolidated into a single publication. During the digitising of the specimens of NCN, a number of unpublished records of plant nematodes reported from protected areas in the Eastern Cape were discovered. 


\section{Materials and methods}

The datasets reflected in the checklist consist of nematodes collected by various nematologists over a period of 30 years. In some cases the collection and extraction methods are not known. The standard procedure of NCN is that soil samples are taken with a garden trowel, spade or soil auger, depending on the terrain in the rhizosphere of the plant. The plants are collected at the same time and the soil and accompanying plant are sealed in plastic bags, placed in a cool box containing ice bricks and transported to the laboratory of NCN where the samples are stored in a cold room at $12{ }^{\circ} \mathrm{C}$. The relevant collection data, including locality, habitat, substrate, moisture regime, soil type, exposure slope, aspect and host plant, are noted in the field.

The nematodes are extracted from the soil using the sugar centrifugal-flotation method (Jenkins 1964). Specimens are killed in water by the gradual application of heat, then fixed and preserved in distilled water, $4 \%$ formaldehyde and $1 \%$ propionic acid (known as FPG), dehydrated to anhydrous glycerine and permanently mounted in anhydrous glycerine on Cobb aluminium slides (Hooper \& Evans 1993; Netscher \& Seinhorst 1969). Nematodes are extracted from plant material using the method described by Kleynhans (1997), and are killed, preserved and mounted in the same way as the nematodes extracted from soil.

The classification of South African plant nematodes followed here is a synthesis of the classification by Maggenti et al. (1988) for Tylenchina; and Decraemer (1995) and Duarte et al. (2010) for Trichodoridae. Authorities for genera regarded as valid here are Hunt, Luc and Manzanilla-López (2005) for Criconemoides; Marais (2001) for Helicotylenchus; Escuer and Arias (1997) for Paralongidorus; Brzeski (1998) for Paratylenchus; and Handoo (2000) for Tylenchorhynchus.

\section{Results and discussion}

The checklist reflects specimens collected between 1968 and 1998 from seven protected areas in the Eastern Cape. The SAPPNS database contains 311 records of nematodes sampled in uncultivated areas in the Eastern Cape, of which 98 records are from localities in protected areas
(Online Appendix 1). The database also contains 505 records of localities sampled in cultivated areas, which include crop fields, plantations, gardens and sports fields. It was found that 80 plant nematode species were reported from protected areas (Table 1), 163 species from uncultivated areas (outside protected areas) and 150 species from cultivated areas.

In total, $230(51 \%)$ of the 455 currently known plant nematode species from South Africa have been recorded from the Eastern Cape. Of these, 29 species were described from the province; 10 of these were described from the protected areas in the province: Criconemoides silvicola Van den Berg 1996, Meloinema silvicola Kleynhans 1988, Ogma tuberculatum Van den Berg 1996, Paralongidorus cebensis (Heyns \& Coomans 1989) Escuer \& Arias 1997, Paralongidorus hanliae Liebenberg, Heyns \& Swart 1993, Scutellonema tsitsikamense Van den Berg 1976, Trichodorus vandenbergae De Waele \& Kilian 1992, Xiphinema erriae Hutsebaut, Heyns \& Coomans 1988, Xiphinema ornatizulu Hutsebaut, Heyns \& Coomans 1989 and Xiphinema simplex Hutsebaut, Heyns \& Coomans 1989. Only M. silvicola, O. tuberculatum, P. cebensis and $S$. tsitsikamense were not reported from other provinces, suggesting endemism.

\section{Acknowledgements}

We thank various colleagues and clients for collecting the samples, the taxonomists at ARC-PPRI and (the former) Rand Afrikaans University for species identification and the South African Biodiversity Information Facility for financial assistance in order to digitise a major portion of NCN.

\section{Competing interests}

The authors declare that they have no financial or personal relationship(s) that may have inappropriately influenced them in writing this article.

\section{Authors' contributions}

M.M. (Plant Protection Research Institute) is the coordinator of SAPPNS, project leader of digitising the national collection and taxonomist responsible for Helicotylenchus, Belonolaimidae, Dolichoridae, Trichodoridae and the

TABLE 1: Number of genera and species of plant nematodes recorded from the Eastern Cape.

\begin{tabular}{|c|c|c|c|c|c|c|c|}
\hline Family & Genera & $\begin{array}{l}\text { Eastern } \\
\text { Cape }\end{array}$ & $\begin{array}{l}\text { Protected } \\
\text { areas }\end{array}$ & $\begin{array}{l}\text { Uncultivated areas } \\
\text { (excluding protected } \\
\text { areas) }\end{array}$ & $\begin{array}{l}\text { Cultivated areas } \\
\text { (crops, plantations, } \\
\text { sports fields) }\end{array}$ & $\begin{array}{l}\text { Species described from } \\
\text { Eastern Cape outside } \\
\text { protected areas }\end{array}$ & $\begin{array}{l}\text { Species described from } \\
\text { Eastern Cape protected } \\
\text { areas }\end{array}$ \\
\hline Anguinidae & 2 & 4 & - & 3 & 2 & - & - \\
\hline Dolichodoridae & 1 & 2 & - & 2 & 1 & - & - \\
\hline Belonolaimidae & 4 & 12 & 3 & 11 & 10 & 2 & - \\
\hline Pratylenchidae & 3 & 15 & 2 & 9 & 13 & 1 & - \\
\hline Hoplolaimidae & 5 & 46 & 21 & 42 & 32 & 3 & 1 \\
\hline Criconematidae & 6 & 47 & 19 & 35 & 26 & 6 & 2 \\
\hline Tylenchulidae & 4 & 17 & 4 & 4 & 13 & - & - \\
\hline Trichodoridae & 3 & 7 & 4 & 5 & 5 & - & 1 \\
\hline Longidoridae & 3 & 63 & 22 & 49 & 34 & 7 & 5 \\
\hline Number of records in SAPPNS database & - & 816 & 98 & 313 & 505 & - & - \\
\hline Number of plant nematode species & - & 230 & 80 & 163 & 150 & 19 & 10 \\
\hline
\end{tabular}

SAPPNS, South African Plant-Parasitic Nematode Survey. 
subfamily Meloidogyninae, and was responsible for writing the draft concept of the manuscript. A.S. (Plant Protection Research Institute) is the taxonomist responsible for Longidoridae, Anguinidae, Aphelenchoididae and the subfamily Heteroderinae, and was responsible for the final review of the manuscript. M.M. and A.S. were both responsible for writing this article.

\section{References}

Brzeski, M., 1998, Nematodes of Tylenchina in Poland and temperate Europe Museum i Instytut Zoologii Polska Akademia Nauk, Warzawa.

Decraemer, W., 1995, The family Trichodoridae: Stubby root and virus vector nematodes, Kluwer Academic Press, Dordrecht. http://dx.doi.org/10.1007/97894-015-8482.

Duarte, I.M., De Almeida, M.T., Brown, D.J.F., Marques, I., Nielsen, R. \& Decraemer, W., 2010, 'Phylogenetic relationships, based on SSU rDNA sequences, among the didelphic genera of the family Trichodoridae from Portugal', Nematology 12(2), 171-180. http://dx.doi.org/10.1163/156854109X461721

Escuer, M. \& Arias, M., 1997, 'Paralongidorus iberiss p.n. and P. monegrensiss p.n. from Spain with a polytomous key to the species of the genus Paralongidorus
Siddiqi, Hooper \& Khan, 1963 (Nematoda: Longidoridae)', Fundamental and Applied Nematology 20(2), 135-148 viewed n.d., from http://horizon and Applied Nematology 20(2), 135-148 viewed n.d., from
documentation.ird.fr/exl-doc/pleins_textes/fan/010009433.pdf

Handoo, Z., 2000, 'A key and diagnostic compendium to the species of the genus Tylenchorhynchus Cobb, 1913 (Nematoda: Belonolaimidae)', Journal of Nematology 32(1), 20-34. PMid:19270946.
Hooper, D.J. \& Evans, K., 1993, 'Extraction, identification and control of plant nematodes', in K. Evans, D.L. Trudgill \& J.M. Webster (eds.), Plant Parasitic Nematodes in Temperate Agriculture, pp. 31-59, CAB International, Wallingford.

Hunt, D.J., Luc, M. \& Manzanilla-López, R.H., 2005, 'Identification, morphology and biology of plant parasitic nematodes', in M. Luc, R.A. Sikora \& J. Bridge (eds.), Plant parasitic nematodes in subtropical and tropical agriculture, 2nd edn., pp. 11-52, CABI Publishing, Wallingford. http://dx.doi. 2nd edn., pp. 11-52, CABI
org/10.1079/9780851997278.0011

Jenkins, W.R., 1964, 'A rapid centrifugal-flotation technique for separating nematodes from soil', Plant Disease Reporter 48, 692.

Kleynhans, K.P.N., 1997, Collecting and preserving nematodes. Manual for a SAFRINET course in practical Nematology, SAFRINET, the Southern African (SADC) LOOP of BioNET-INTERNATIONAL, Pretoria.

Maggenti, A.R., Luc, M., Raski, D.J., Fortuner, R. \& Geraert, E., 1988, 'A reappraisal of Tylenchina (Nemata). 11. List of generic and supra-generic taxa, with their junior synonyms', Revue de Nématologie 11, 177-188.

Marais, M., 2001, 'A monograph of the genus Helicotylenchus Steiner, 1945 (Nemata: Hoplolaimidae)', PhD dissertation, Department of Entomology and Nematology, University of Stellenbosch.

Marais, M., 2006, 'South African Plant-Parasitic Nematode Survey (SAPPNS)', Plant Protection News 67, 6.

Netscher, C. \& Seinhorst, J.W., 1969, 'Propionic acid better than acetic acid for killing nematodes', Nematologica 15, 286.

Van den Berg, E., 1996, 'A first list of plant-parasitic nematodes from the Tsitsikamma National Park, with descriptions of two new species of the subfamily Criconematinae', Koedoe 39(1), 43-54. http://dx.doi.org/10.4102/ koedoe.v39i1.281

Yeates, G.W., Bongers, T., De Goede, R.G.M., Freckman, D.W. \& Georgieva, S.S. 1993, 'Feeding habits in nematode families and genera - an outline for soil ecologists', Journal of Nematology 25, 315-331. 